\title{
PROTOTYPE SISTEM MANAJEMEN KINERJA PEGAWAI NEGERI KANTOR URUSAN AGAMA CIBODAS KOTA TANGERANG
}

\author{
Abdul Hamid Arribathi ${ }^{1}$,Wahyu Hidayat ${ }^{2}$,Rinaldy Qodar Saputra ${ }^{3}$ \\ ${ }^{1,2}$ Dosen STMIK Raharja Jurusan Sistem Informasi, ${ }^{3}$ Mahasiswa STMIK Raharja Jurusan Teknik \\ Informatika \\ 1,2,3 J1.Jendral Sudirman No.40, Modern Cikokol, Tangerang \\ e-mail:1 ${ }^{1}$ abdulhamid@raharja.info, ${ }^{2}$ wahyu@raharja.info, ${ }^{3}$ rinaldy@raharja.info
}

\begin{abstract}
Abstrak
Kantor Urusan Agama (KUA) yaitu, kantor yang melakukan beberapa kegiatan untuk agama (Islam) terutama dalam perkawinan dan juga perceraian. Dalam hal ini tentu saja perkembangan teknologi di lembaga pemerintah seperti KUA sangat penting karena banyaknya informasi yang akan diolah menjadi data. Oleh sebab itu, peneliti akan melakukan penelitian pada salah satu kantor KUA yang bertempat di kecamatan Cibodas, Kota Tangerang dan menemukan masalah yang ada yaitu, sistem laporan kinerja pegawai negeri masih berupa semi-komputerisasi atau bisa dikatakan masih menggunakan MS.Excel dalam pengerjaannya. Oleh sebab itu, peneliti akan menyusun sistem laporan kinerja pegawai negeri di KUA cibodas menjadi lebih terkomputerisasi dengan digunakannya bahasa pemrograman berbasis Java Desktop yang digunakan pada perangkat lunak NetBeans IDE dan dibantu dengan database online seperti MySQL dalam penyimpanan data atau berkasberkasnya dapat disimpan dengan baik. Dengan digunakannya sistem ini diharapkan untuk dapat memudahkan pembuatan laporan kinerja pegawai negeri dan data tersimpan lebih terstruktur, efisien, dan efektif.

Kata kunci : Java Dekstop, NetBeans IDE, MySQL
\end{abstract}

\begin{abstract}
Office of Religious Affairs (KUA) namely, offices that perform some activities for religion (Islam), especially in marriage and also divorce. In this case, of course, the development of technology in government institutions such as KUA is very important because the amount of information that will be processed into data. Therefore, the researcher will conduct research on one of the KUA offices located in Cibodas sub-district, Tangerang City and find the problem that is, the civil servant performance report system that is still semi-computerized or it can be said still using MS.Excel in the process. Therefore, researchers will develop a civil servant performance report system in KUA cibodas to be more computerized using the Java Desktop programming language used in NetBeans IDE software and assisted with online databases such as MySQL in data storage or files can be stored properly. With the use of this system is expected to facilitate the preparation of civil service performance reports and stored data more structured, efficient, and effective.
\end{abstract}

Keywords : Java Dekstop, NetBeans IDE, MySQL 


\section{PENDAHULUAN}

Perkembangan teknologi yang begitu pesat dari tahun ke tahun tentu menuntut kita sebagai masyarakat untuk melangkah lebih maju, begitu pula perkembangan teknologi dalam bidang pemerintahan, pendidikan, dan ekonomi . kemajuan akan teknologi yang begitu pesat dirasa sangat penting untuk institusi pemerintahan terutama dalam hal mengolah informasi yang kemudian akan disimpan sebagai data, salah satunya yaitu institusi pemerintahan yang mengolah informasi berupa urusan keagamaan seperti kantor KUA.

Kantor Urusan Agama (KUA) yaitu, kantor yang melaksanakan beberapa kegiatan ke agamaan (islam) terutama dalam pernikahan atau perceraian. Oleh sebab itu, perkembangan teknologi di dalam institusi pemerintahan seperti KUA sangat penting karena adanya pengolahan informasi yang akan dijadikan sebuah data bagi masyarakat berupa identitas. Selain itu di kantor KUA tidak hanya sebatas mengolah informasi dalam hal kemasyarakatan saja tetapi di kantor KUA juga mengolah informasi pegawai PNS seperti halnya data pegawai , data kegiatan/pekerjaan pegawai dan sasaran kinerja pegawai (skp)/penilaian kinerja pegawai (pkp).

Oleh sebab itu, peneliti akan melakukan penelitian di salah satu institusi pemerintahan yaitu Kantor Urusan Agama (KUA) yang bertempat pada cibodas kota tangerang - peneliti menemukan adanya kekurangan dalam laporan kinerja harian PNS yang ada di KUA cibodas ini , dimana laporan masih berupa semi komputer yang masih digunakannya MS.Excel dalam pembuatannya.

Dalam penelitian ini peneliti akan membuat sistem baru berupa Aplikasi laporan kinerja harian PNS dengan digunakannya software Java NetBeans IDE 8.2 guna mempermudah pembuatan laporan kinerja harian PNS yang di dalamnya mencangkup data pegawai, data kegiatan, catatan harian , SKP dan catatan alibi (alasan ketidak hadiran pegawai) di KUA kecamatan cibodas kota tangerang.

\section{METODE PENELITIAN}

1. Penelitian Evaluasi

Menurut Sugiyono (2013:224) mengunpulkan data merupakan cara yang paling strategis di dalam penelitian, sebab tujuan dari penelitian adalah memperoleh data.

A. Teknik Wawancara, Menurut Esterberg dibuku Sugiyono (2013:231) wawancara ialah merupakan pertemuan dua orang atau lebih untuk pertukaran informasi melalui tanya jawab, sehingga dapat ditentukannya makna di dalam suatu topik tertentu.

B. Teknik Pengamatan, Sutrisno Hadi dibuku Sugiyono (2013:145) berpendapat, pengamatan merupakan sesuatu proses yang kompleks, sesuatu proses yang disusun dari proses biologis juga psikhologis. Yang terpenting ialah proses pengamatan serta ingatan.

2. Analisi Data

Menurut Sugiyono (2013:244) analisis data ialah proses pencarian serta penyusunan secara sistematis dari hasil wawancara, laporan/catatan lapangan dan juga bahan lainnya, sehingga mudah dipahami.

\section{Prototype}

Setelah semua data sudah dikumpulkan dan disusun menjadi sebuah rangkaian konsep, selanjutnya dilakukan pembuatan prototype atau gambaran rangkaian sistem kerja aplikasi yang dibuat lebih mudah dimengerti. 


\section{Simulasi}

Gambaran sistem bersekala kecil dan juga terjadinya proses manipulasi dan kontrol terhadap sistem itu sendiri.

\section{Literature Review}

[1] Peneliti yang dilakukan Junaidi, M. Yusuf Effendy, Hamzah Hartono dengan judul "REKAYASA MODEL APLIKASI SISTEM PRODUCT KNOWLADGE UNTUK MENDUKUNG PENGAMBILAN KEPUTUSAN DALAM MENENTUKAN KINERJA KARYAWAN " penelitian memuat mampu melakukan proses penciptaan kuis product knowledge dengan cepat serta sesuai kebutuhan bagian atau posisi, selain itu sistem juga harus mampu melakukan random soal dan sharing soal dengan beberapa kebutuhan, setelah itu sistem juga harus mampu melakukan proses penilaian dan rekapitulasi dengan cepat serta akurat, serta tersimpan dengan baik sebagai data yang kemudian bisa digunakan.

[2] Peneliti yang dilakukan Junaidi, Ladyca Anugrah, Adhitya D.P "MODEL APLIKASI MONITORING SISTEM ABSENSI SIDIK JARI SEBAGAI PENDUKUNG KEPUTUSAN UNTUK PENILAIAN KINERJA PEGAWAI" penelitian ini memuat sistem informasi absen, guna meminimalkan permasalahan yang ada, dengan membangun sistem ini diharapkan dapat membantu pegawai dalam melakukan proses pengolahan data/informasi serta membantu para pegawai melakukan proses absensi.

[3] Peneliti yang dilakukan Anton Tirta Komara dan Euis Nelliawati dengan judul " PENGARUH KOMPENSASI, MOTIVASI DAN KEPUASAN KERJA TERHADAP KINERJA PEGAWAI NEGERI SIPIL (PNS) DI LINGKUNGAN RUMAH SAKIT UMUM DAERAH (RSUD) KOTA BANDUNG " penelitian ini memuat Bagaimana kompensasi, motivasi kerja, kepuasan kerja dan kinerja pegawai secara individual atau pun simultan.

[4] Peneliti yang dilakukan Aurelia Potu dengan judul "KEPEMIMPINAN, MOTIVASI, DAN LINGKUNGAN KERJA PENGARUHNYA TERHADAP KINERJA KARYAWAN PADA KANWIL DITJEN KEKAYAAN NEGARA SULUTTENGGO DAN MALUKU UTARA DI MANADO" penelitian ini memuat upaya dalam menciptakan kinerja yang baik dan juga efektif .Kendala-kendala yang dihadapi yaitu, absen karyawan dari bulan ke bulan mengalami penurunan, datang terlambat, pulang lebih awal dan juga penyelesaian tugas yang belum optimal.

[5] Penelitian yang dilakukan Saefudin, Sri Wahyuningsih berjudul "SISTEM PENDUKUNG KEPUTUSAN UNTUK PENILAIAN KINERJA PEGAWAI MENGGUNAKAN METODE ANALYTICAL HIERARCHY PROCESS (AHP) PADA RSUD SERANG" penelitian ini memuat sistem yang berupa mendukung putusan penilaian kinerja pegawai. Memakai Analitycal Hierarchy Process di RSUD Serang. Metode Analitycal Hierarchy Process, sesuatu model yang komprehensif serta terstruktur dalam pengambilan keputusan.

1. Permasalahan

\section{HASIL DAN PEMBAHASAN}

Berdasarkan analisa, permasalahan di atas adalah sistem yang masih semi Komputer, yang menggunakan MS.EXCEL

1. Data pegawai hanya bisa di input satu data per pegawai.

2. Pembuatan laporan masih terlalu lama, karena banyaknya pengetikan.

3. Tidak terpeliharanya data, di karena kan database yang masih offline.

Di bawah ini adalah tampilan sistem lama berupa MS.EXCEL, sistem yang digunakan pun merupakan sistem milik KUA Bantul. 


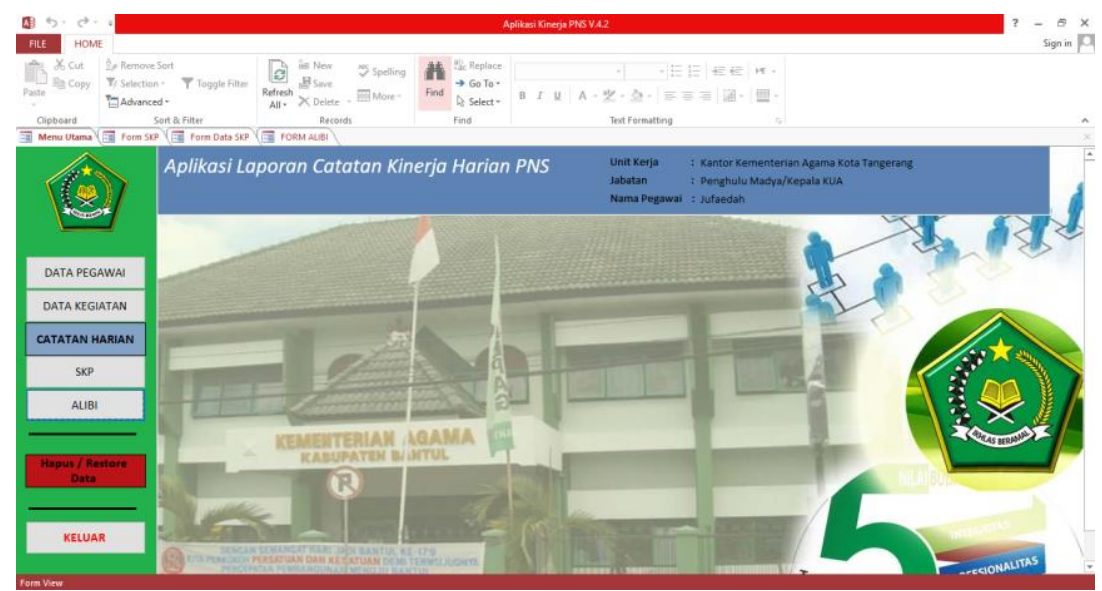

Gambar.1 sistem lama

2. Pemecahan Masalah

Berdasarkan penelitian dari permasalahan, terdapat di sistem lama peneliti merancang sistem baru yang lebih terkomputerisasi dengan dimilikinya sistem login yang dapat mengamankan data serta mempermudah dalam pembuatan laporan. Media yang digunakan untuk merancang sistem yaitu NetBeans IDE. serta database MySQL. Di bawah ini gambar prototype sistem baru :

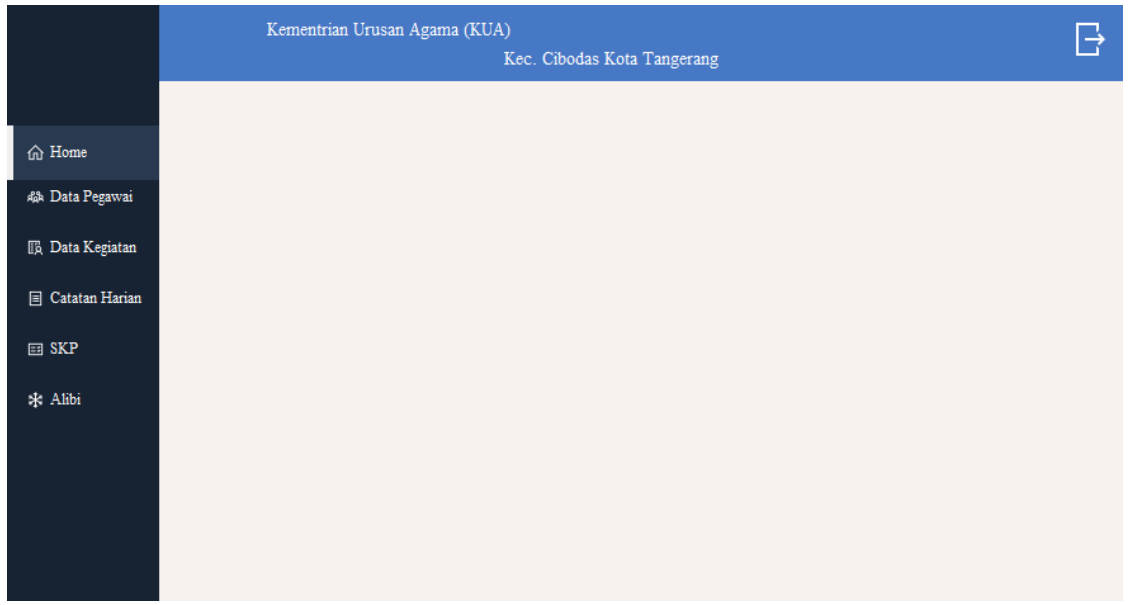

Gambar.2 Tampilan Menu prototype sistem

\section{Penggunaan Software}

\section{A. NetBeans}

NetBeans adalah tool/perangkat guna merancang program dalam pemrograman dekstop dan bahasa dipakai ialah Java dengan berbasis grafis. Untuk merancang suatu aplikasi, di NetBeans tersedia modul (modular) dan modul itu sendiri merupakan Java Archive yang juga memuat kelas-kelas di java serta berinterkasi pada NetBeans Open API.

B. MySQL

Dalam buku Abdul Kadir (2014:242), SQL (Structured Query Language) ialah bahasa yang dipakai dalam mengakses data dan juga yang tergolong relasional. Sebenarnya SQL tidak hanya mengambil data (query), sql juga dapat dipakai guna menciptakan tabel (CREATE), menghapus tabel (DELETE), menambahkan data yg ada ke tabel (INSERT), menghapus data tabel (DROP), mengganti data di tabel (UPDATE), dan juga berbagai operasi lain. 
4. Implementasi

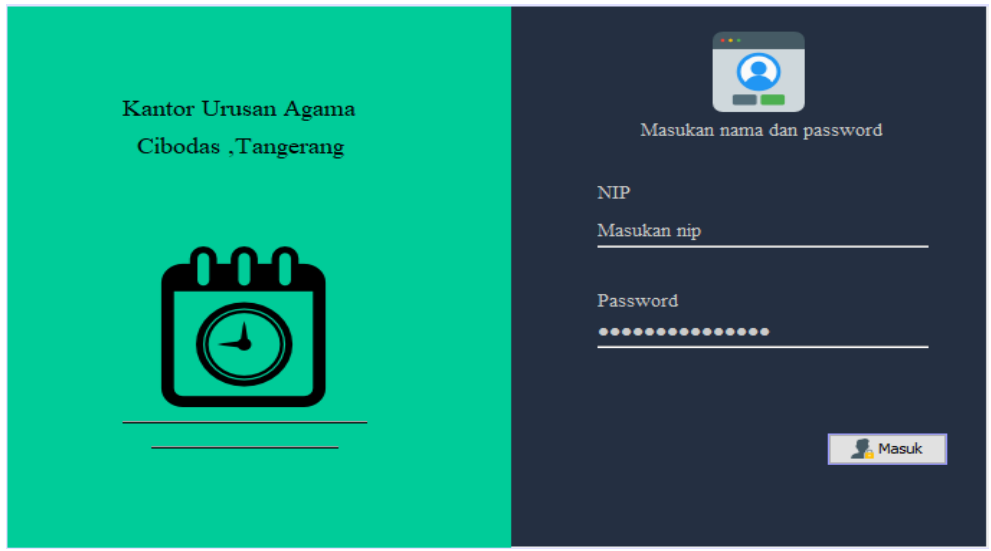

Gambar.3 Login

Form login, dimana keutamaan nya adalah memberikn akses yang aman kepada program agar tidak ada user/pengguna lain yang dapat masuk selain dari pegawai setempat yang tersimpan datanya pada database yang ada. Form diatas terdapat :

1. Nip : Dimana nip diisi data ID pada database masing-masing pegawai.

2. Password : Sama seperti nama dimana password diisi sesuai Password masing-masing pegawai.

3. Masuk : Masuk adalah sebuah button perintah yang berfungsi mengecek apakah Nama dan Password yang di input oleh user/pegawai benar atau salah . jika benar maka akan masuk pada tampilan berikutnya .

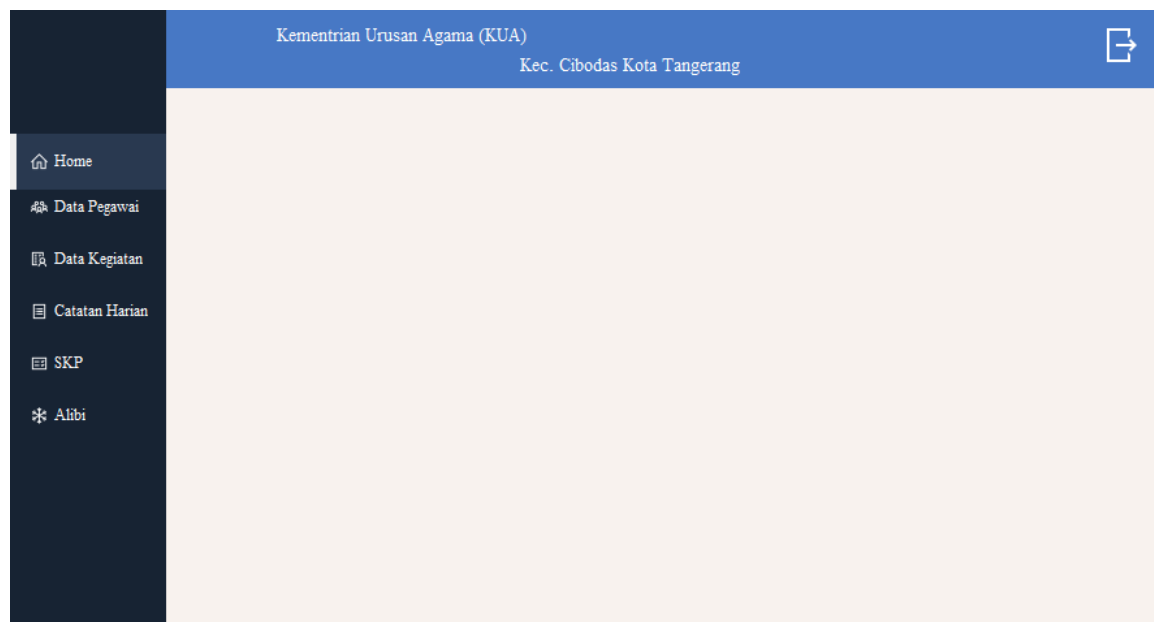

Gambar.4 Tampilan Menu

Pada gambar diatas merupakan tampilan menu dimana tampilan menu ini memiliki subsub antara

lain :

1. Sub Home

2. Sub Data Pegawai

3. Sub data Kegiatan kegiatan.

4. Sub Catatan harian
: Pada sub ini berfungsi sebagai acuan menu.

: Pada sub data pegawai akan berisi data-data pegawai.

: Pada sub data kegiatan akan berisi kumpulan data-data

: Pada sub catatan harian berisi form menu input kegiatan. 
5. Sub SKP

6. Sub Alibi kantor.
: Pada sub SKP berisi form inputan SKP.

: Pada sub Alibi berisi alasan tidak hadirnya pegawai ke

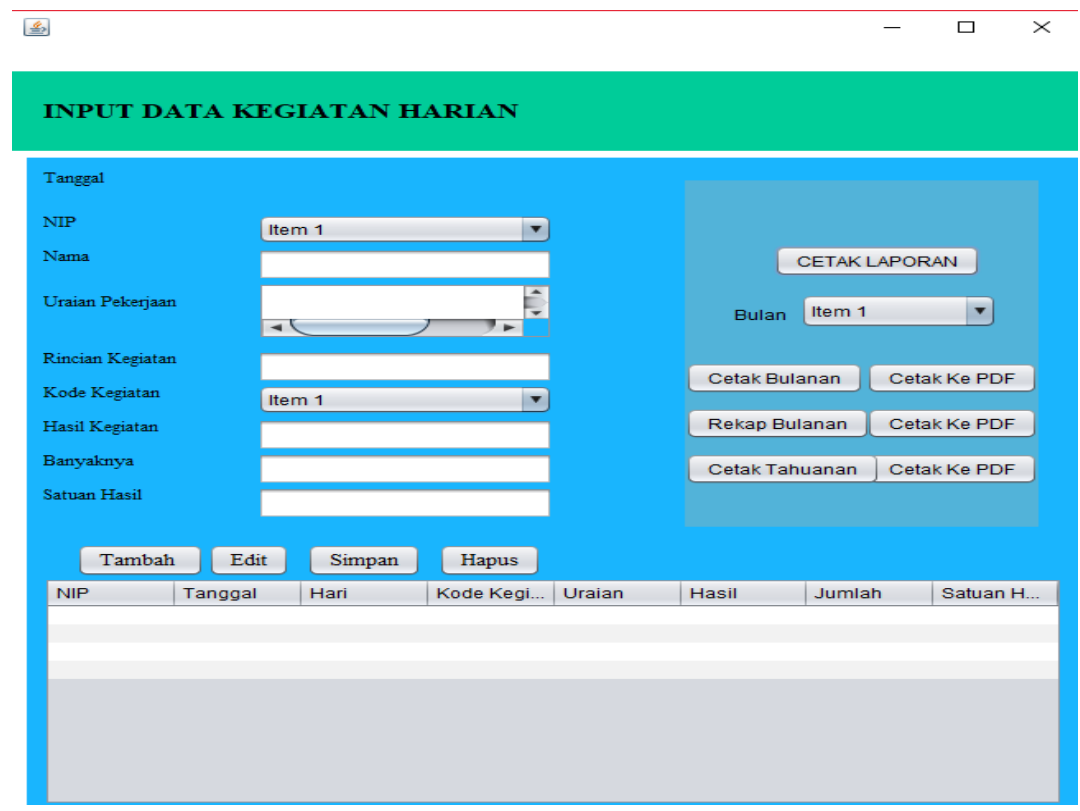

Gambar.5 form input kegiatan

Pada form inputan kegiatan, pegawai mengisi laporan kegiatan yang dikerjakan berupa uraian pekerjaan, rincian kegiatan yang dikerjakan , kode kegiatan, hasil kegiatan yang dikerjakan, banyaknya kegiatan yang dikerjakan, dan satuan hasil kegiatan .

Fungsi penggunaan button diatas :

1. Tambah harian.

2. Edit

3. Simpan

4. Hapus database.

5. Cetak Laporan : Button Cetak Laporan berfungsi guna mencetak/print laporan data harian.

6. Cetak Bulanan : Button Cetak Bulanan berfungsi guna mencetak/print laporan selama satu

bulan.

7. Cetak Tahunan : Button Tahunan berfungsi guna mencetak laporan selama setahun.

8. Cetak PDF : Button Cetak PDF berfungsi guna mencetak laporan ke bentuk PDF. 


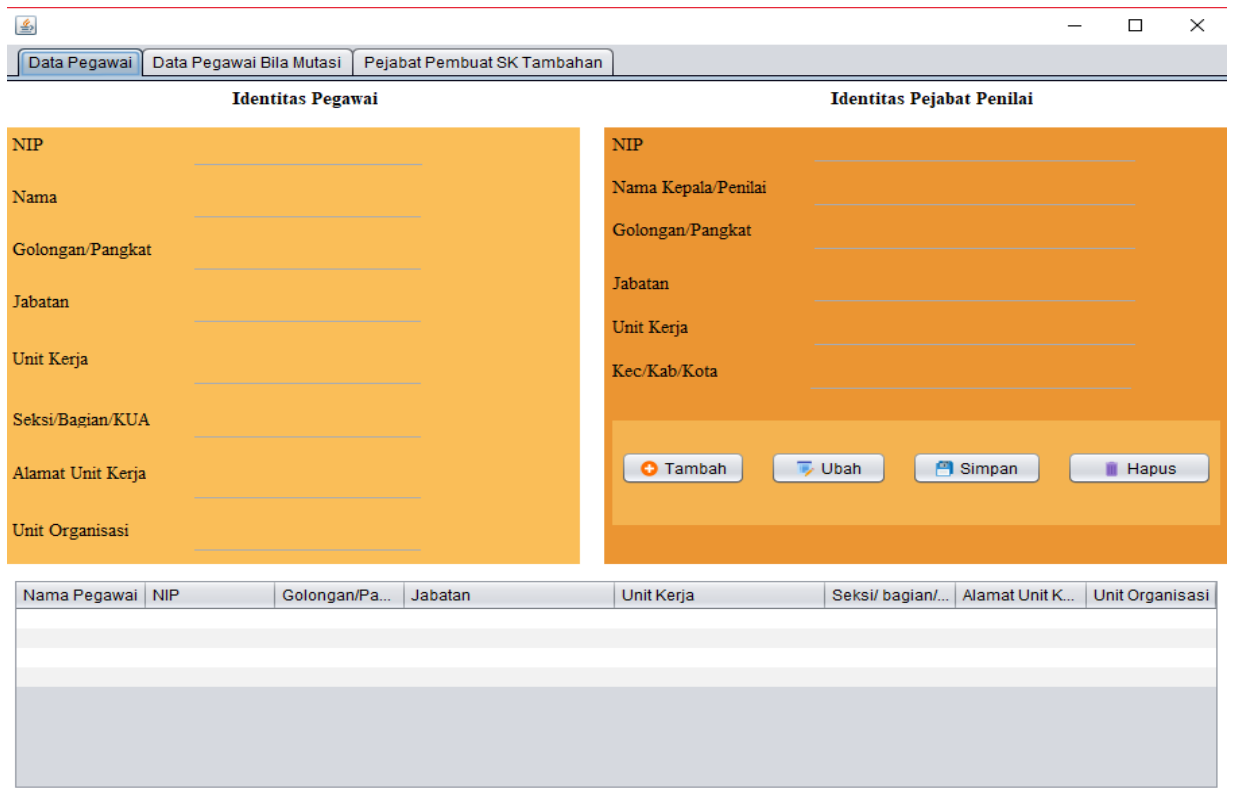

Gambar.6 form data pegawai

Gambar diatas ialah form data pegawai, dimana perubahan atau penambahan data pegawai bisa langsung di manipulasi didalam tabel yang tersedia .

Terdapat juga sub-sub yang berupa :

1. Data pegawai bila mutasi, berisi data pegawai mutasi atau yang dimutasi . tampilan sesuai seperti data pegawai.

2. Pejabat pembuat SK tambahan, berisi data SK tambahan.

Fungsi penggunaan button diatas :

1. Tambah : Button tambah berfungsi jika pegawai akan menginput kegiatan harian.

2. Edit : Button edit berfungsi mengedit/merubah data yang terinput jika ada kesalahan

penulisan.

3. Simpan : Button Simpan berfungsi menyimpan informasi/data yang terinput.

4. Hapus : Button Hapus disini berfungsi menghapus data kegiatan pada database.

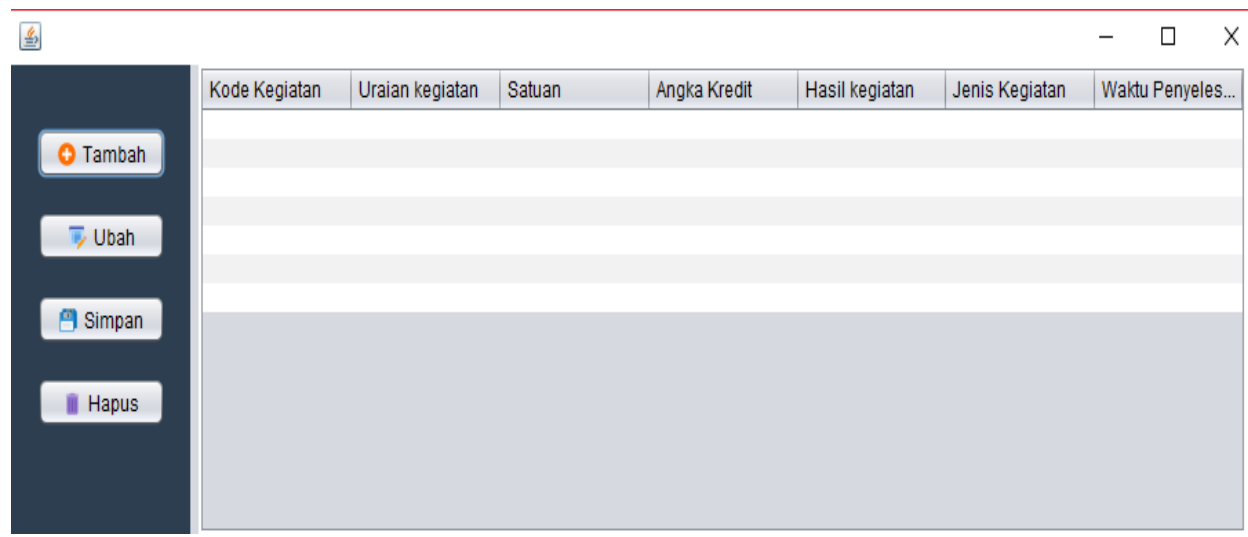

Gambar.7 form data kegiatan

Gambar 7 diatas berisi form data kegiatan dimana seluruh data kegiatan/pekerjaan pegawai negeri KUA tersimpan . data tersebut dapat di manipulasi dengan adanya button :

Fungsi penggunaan button diatas :

1. Tambah : Button tambah berfungsi jika pegawai akan menginput kegiatan harian.

2. Edit : Button edit berfungsi mengedit/merubah data yang telah terinput jika ada 
kesalahan penulisan.

3. Simpan : Button Simpan berfungsi menyimpan informasi/data yang terinput.

4. Hapus : Button Hapus disini berfungsi menghapus data kegiatan pada database.

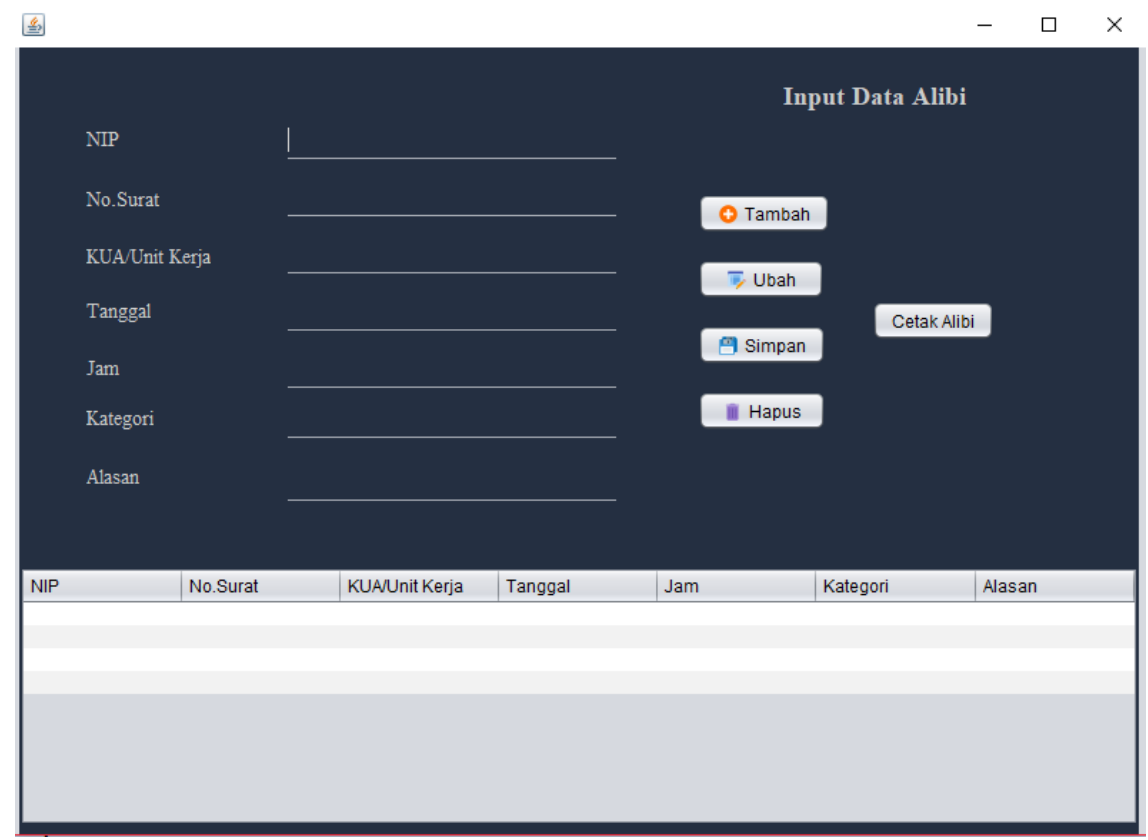

Gambar.8 Form Data Alibi

Gambar diatas ialah form data alibi yang berfungsi sebagai alasan kenapa pegawai negeri tidak hadir di kantor. Dimana seorang pegawai yang tidak hadir harus memberikan keterangan alasan mengapa ia tidak hadir dengan mengisi seperti gambar form diatas dan setelah itu harus mencetaknya dalam bentuk surat.

Berikut ini fungsi-fungsi button diatas :

1 Tambah : Button tambah berfungsi jika pegawai akan menginput kegiatan harian.

2 Edit : Button edit berfungsi mengedit data yang sudah di input jika ada kesalahan

3 Simpan : Button Simpan berfungsi menyimpan informasi/data yang terinput.

4 Hapus : Button Hapus berfungsi menghapus data kegiatan pada database.

5 Cetak Alibi : Button Cetak Alibi berfungsi untuk mencetak dokumen dalam bentuk surat. 


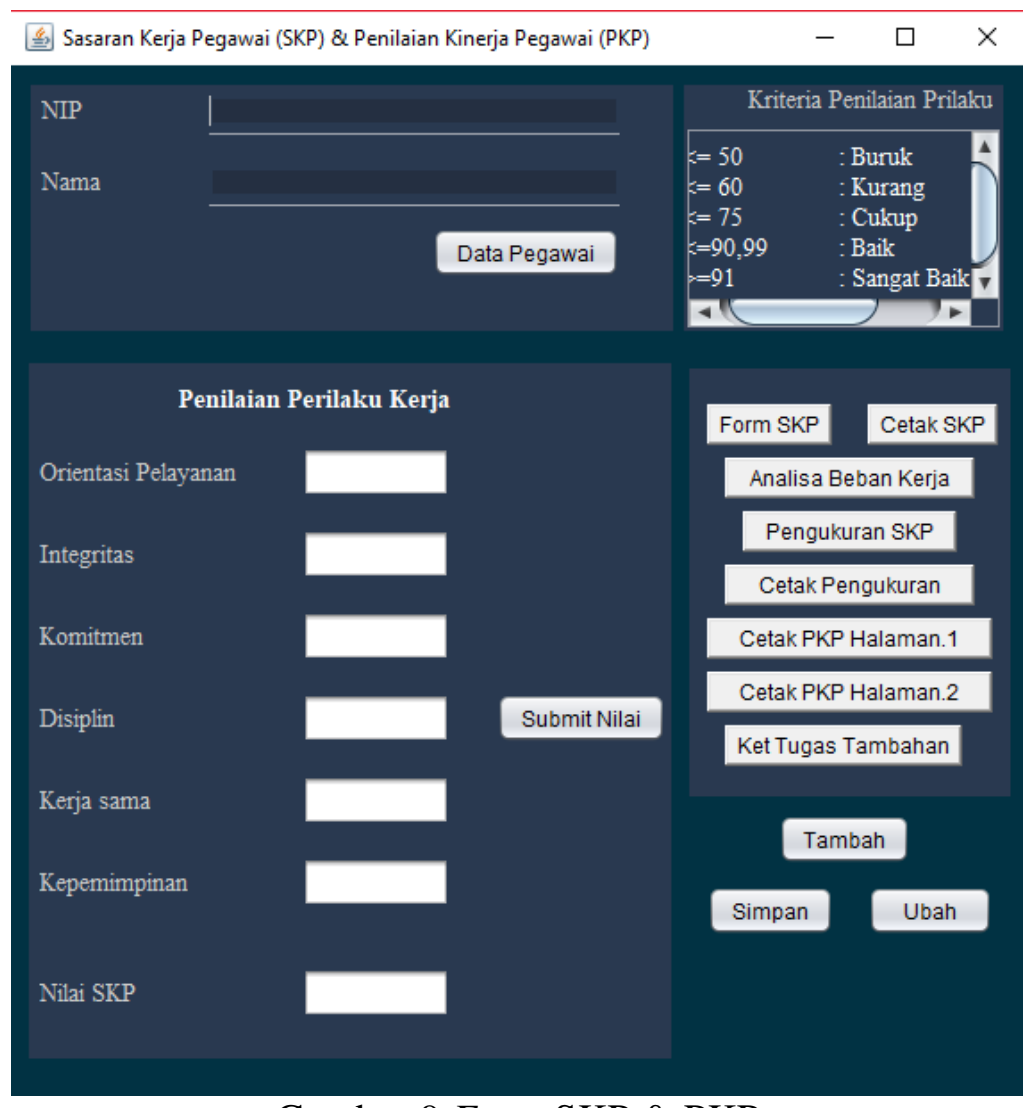

Gambar.9 Form SKP \& PKP

Pada Form SKP \& PKP diatas berfungsi sebagai penilaian kinerja pegawai. Penilaian diberikan sesuai dengan data kegiatan harian kerja pegawai dan juga berdasarkan perilaku pegawai selama bekerja. Kriteria penilaian meliputi :

1. Orientasi Pelayanan

2. Integritas Kerja

3. Komitmen Kerja

4. Disiplin Kerja

5. Kerja Sama

6. Kepemimpinan Kerja

Berikut ini fungsi-fungsi button diatas :

1. Tambah : Button tambah berfungsi jika pegawai akan menginput kegiatan harian.

2. Edit

: Button edit berfungsi mengedit/merubah data yang terinput jika ada kesalahan penulisan.

3. Simpan : Button Simpan berfungsi menyimpan data yang terinput.

4. Submit Nilai : Button ini digunakan sebagai proses penghitungan nilai.

5. Data Pegawai : Button ini berfungsi pemilihan data pegawai yang akan diberikan nilai

\section{SKP.}

6. Form SKP $\quad$ : Button ini berfungsi untuk melihat data-data SKP.

7. Pengukuran SKP : Digunakan sebagai pengukuran data SKP pegawai.

Selain fungsi button diatas, juga ada fungsi button yang tugasnya mencetak dokumen, seperti button dibawah ini :

1. Cetak SKP

2. Analisa Beban Kerja 
3. Cetak Pengukuran SKP

4. Cetak PKP Halaman.1

5. Cetak PKP Halaman.2

6. Keterangan Tugas Tambahan

\section{KESIMPULAN}

Berdasarkan analisa yang dilakukan/laksanakan setelah adanya pembuatan sistem baru peneliti menyimpulkan Pembuatan laporan kinerja PNS pada KUA cibodas kota tangerang menjadi lebih efisien dan efektif karena:

1. Program aplikasi yang bersifat user friendly mudah dipahami serta digunakan.

2. Lebih mudah mendapatkan informasi laporan data pegawai dengan terstrukturnya data.

3. Pembuatan laporan jadi lebih cepat.

4. Terpeliharanya data karena menggunakan database online.

\section{SARAN}

Berdasarkan sistem yang peniliti buat seperti diatas tentunya masih ada kekurangan antara lain :

1. Sistem masih berupa dekstop, diharapkan akan ada peneliti lain yang mengupdatenya menjadi web base.

2. Database yang digunakan masih gratis, jadi jika ada banyaknya data yang diproses di khawatirkan sistem akan lag / akan terlalu lama memproses data.

\section{DAFTAR PUSTAKA}

[1]. Junaidi, Effendy .J, M. Y., \& Hartono, H, (2015). REKAYASA MODEL APLIKASI SISTEM PRODUCT KNOWLADGE UNTUK MENDUKUNG PENGAMBILAN KEPUTUSAN DALAM MENENTUKAN KINERJA KARYAWAN. CERITA Journal, 1(1), 46-55.

[2]. Junaidi, A. Ladyca, P. D. Adhitya, (2015). MODEL APLIKASI MONITORING SISTEM ABSENSI SIDIK JARI SEBAGAI PENDUKUNG KEPUTUSAN UNTUK PENILAIAN KINERJA PEGAWAI. Konferensi Nasional Sistem \& Informatika, 938-942.

[3]. K.T Anton \& N. Euis, (2014). PENGARUH KOMPENSASI,MOTIVASI DAN KEPUASAN KERJA TERHADAP KINERJA PEGAWAI NEGERI SIPIL (PNS) DI LINGKUNGAN RUMAH SAKIT UMUM DAERAH (RSUD) KOTA BANDUNG. Jurnal Ekonomi, Bisnis \& Entrepreneurship, Vol. 8, No. 2, 73-85.

[4]. Potu Aurelia, (2013). KEPEMIMPINAN, MOTIVASI DAN LINGKUNGAN KERJA PENGARUHNYA TERHADAP KINERJA KARYAWAN PADA KANWIL DITJEN KEKAYAAN NEGARA SULUTTENGGO DAN MALUKU UTARA DI MANADO. Jurnal EMBA, Vol.1 No.4 , 1208-1218.

[5]. Saefudin \& W. Sri, (2014). SISTEM PENDUKUNG KEPUTUSAN UNTUK PENILAIAN KINERJA PEGAWAI MENGGUNAKAN METODE ANALYTICAL HIERARCHY PROCESS (AHP) PADA RSUD SERANG. Jurnal Sistem Informasi, Vol- 1, No.1, 33-37.

[6]. Sugiyono, 2013. Metode Penelitian Kualitatif, Kuantitatif dan R\&D. Alfabeta, Bandung.

[7]. Kadir, Abdul, 2014. Pengenalan Sistem Informasi Edisi Revisi. CV. Andi Offset, Yogyakarta. 